\title{
Adolescent's self-concept: Understanding the role of gender and academic competence
}

Rath, Sangeeta

Utkal University, Odisha, India (sangeeta.rath@yahoo.com)

Nanda, Sumitra $\bowtie$

Utkal University, Odisha, India (snsumitrananda@gmail.com)

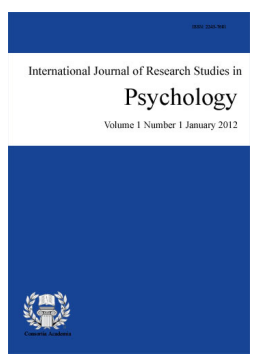

ISSN: 2243-7681 Online ISSN: 2243-769X

OPEN ACCESS

\section{Abstract}

An attempt has been made to examine the effect of gender and academic competence on the self-concept of adolescents. The study adopted a 2 (academically competent versus academically less-competent adolescents) $\times 2$ (boys versus girls) factorial design. In the present study, two hundred forty adolescents (120 academically competent adolescents securing $80 \%$ or more marks and 120 academically less-competent adolescents securing 50\% or fewer marks) are randomly sampled from different urban colleges of Odisha. In each group of 120 adolescents, there are 60 boys and 60 girls. All the subjects are first year graduate students. The participants of all the four groups are compared with respect to their self-concept. The result indicated that academically competent adolescents have higher physical, moral, personal, family, social and overall self-concept than less-competent ones. The strength of association between personal self-concept and overall self-concept in boys is higher than the association found in girls. Similarly, the strength of association between physical self- concept and overall self-concept, as well as social self-concept and overall self-concept is higher in girls than that of the boys.

Keywords: self-concept; adolescent; gender differences; academic achievements; student competency 


\section{Adolescent's self-concept: Understanding the role of gender and academic competence}

\section{Introduction}

Adolescence is the developmental period of transition between childhood and adulthood; it involves biological, cognitive and socio-emotional changes. These changes transform the young person's vision of the self into more complexes, well-organized and consistent picture. Self-conception of adolescents changes in structure. As well as content; structurally it becomes more differentiated and organized. Adolescents are more likely to employ complex, abstract and psychological self-characterization. Self-esteem, the evaluative side of self-concept is also modified during these years. Adolescent's well organized self-description and expanded sense of self-esteem provide the cognitive foundation for constructing an identity.

The self has been defined as that part of one's personality of which one is aware. Self-concept is "the set of perceptions or reference points that the subject has about himself; the set of characteristics, attributes, qualities and deficiencies, capacities and limits, values and relationships that the subject knows to be descriptive of himself and which he perceives as data concerning his identity" (Hamachek, 1981; Machargo, 1991). Shavelson, Hubner, and Stanton (1976) define the term self-concept as the perception that each one has about him, formed from experiences and relationships with the environment, where significant people play an important role. According to Harter (1986) general or global self-concept is determined by the degree of importance that we assign to each of its specific components. If, when describing ourselves, our value judgments are satisfactory, then we obtain a positive global self-concept; in the opposite case we generate negative feelings and thus produce a negative global self-concept. In adolescence, school/college experience plays an important role in the development of self-perception and can have powerful and long lasting effect on the self-esteem of the adolescents.

Academic competency is among the most demanding cognitive and motivational challenge that growing adolescents' face in their life. The importance of academic competence lies in the fact that academic records in the school/college life pre-dominate social reactions and adolescents' future occupational picture. The growing sense of personal control and self-esteem in adolescents as a result of academic achievement serve as a major personal force in their ultimate level of accomplishment. Studies have suggested that academic competence may be an important influence on an adolescent's self-concept. For instance, Marsh and Yeung (1997) found that not only can adolescents' level of academic self-concept affects their later performance in school; their self-concepts are also influenced by their prior academic achievement. Hence, the relationship between self-concept and academic achievement seems to be reciprocal in nature, with each affecting the other. Academic achievement and self- concept are strong predictors of each other.

Individuals with a low self-concept have shown low commitment to academic performance. Cwiok (1996) reported that self- concept was significantly related to academic achievement. An increasing amount of evidence supports the theory that there is a correlation between self-concept and achievement in school (Bell and Ward, 1980). Successful students feel higher sense of personal worth and somewhat feel better about themselves. In general, the higher are the grade averages, the more likely the student is to have a high level of self- acceptance. Strathe and Hash (1979) write: "A significant relationship among academic achievement, school satisfaction, and self-esteem has been reported for students at all grade levels from primary grades through college."

There are two seemingly conflicting views regarding the role of gender on the self-concept of adolescents. Some researchers suggest that young girls show lower self-esteem compared to boys (Orenstein, 1994; Marsh \& Hattie, 1996; Oliva, 1999). According to them these differential patterns of self-appraisal have their origins partly in parental gender linked beliefs and partly in cultural stereotypes regarding their capabilities. Some other empirical studies have found no gender difference in the self-esteem of the adolescents. In recent years Indian 
family life has undergone so many transformations, there have been remarkable attitudinal changes regarding women. The women are no longer seen to have assumed the role of secondary earners in their families; rather they have risen to the height of primary earners or at least co-earners. In many fields, women prove their intelligence, efficiency and expertise as their male counterparts. Men and women have different beliefs about their strong points and derive their self-esteem from different sources. Women in our society are judged on the basis of their physical beauty and attractiveness. Intelligence, academic excellence is considered less appropriate criteria for assessing women. In a major review of research studies, the consensus is that physical attractiveness is of great importance for women than for men (Feingold, 1990). Young adolescent girls are very much aware of the prevailing cultural standard of attractiveness. When they meet these standards, their self-esteem is enhanced. If they are not able to meet the standards, their self-esteem is harmed. They face formidable challenges in meeting the punishing cultural standards of attractiveness. During early adolescence, sometimes there is a decline in the self-esteem of girls for negative body image.

Evidence suggests that men derive self-esteem more from individuating themselves from others (i.e. feeling unique in comparison with others), where as women derive self-esteem in terms of their connection to others. Cross and Madson (1997) argue that many of the sex differences we observe in behavior are due to different ways men and women define themselves. Men maintain an independent sense of self that is separate from others; women by contrast, maintain an interdependent sense of self in which others are integrated into the self. Men are more likely to describe themselves in terms of their independence from others (emphasizing personal attributes and skills) and women are more likely to describe themselves in terms of their connections to others (emphasizing roles, relationship to others). Andrew (2002) found that boys scored significantly lower on social self-concept than girls. In this study, it is expected that in case of girls physical and social self will influence their overall self-concept whereas in case of boys personal self will determine their overall self-concept.

\section{Method}

In this investigation, a series of activities were carried out to test the effect of gender and academic competence on the self-concept of adolescents.

\subsection{Subject}

In the present study, two hundred forty adolescents (120 academically competent adolescents securing $80 \%$ or more marks and 120 academically less-competent adolescents securing $50 \%$ or fewer marks) were randomly sampled from different urban colleges of Odisha. In each group of 120 students, there were 60 boys and 60 girls. All the subjects were +3 first year students. They belonged to the same age group. Care was taken to sample groups equated with respect to their socio-economic status.

\subsection{Measure}

In the present study, measure of Tennessee self-concept scale is applied.

Tennessee Self-concept Scale. The Tennessee self-concept scale is well standardized, widely applicable and a multidimensional scale. The scale consists of hundred self descriptive statements which the subject uses to portray picture of him or herself. The scale is self administering for either individuals or groups and can be used with subject age 12 or higher and having at least a sixth grade reading level. It is applicable to the whole range of psychological adjustment from healthy, well adjusted people to psychotic patients.

The scale is intended to summarize an individual's feeling of self-worth, the degree to which the self-image is realistic, and whether or not that self-image is a deviant one. As well as providing an overall assessment of self-esteem, the TSCS measures five aspects of self-concept like physical self, morale self, personal self, family self and social self. In this scale subject has to respond in a five point scale. Respondents were asked to respond to each statement by putting a cross $(\mathrm{X})$ mark on the appropriate number in the bracket of his/her choice, such as 
Rath, S. \& Nanda, S.

1(completely false), 2 (mostly false), 3 (partly false and partly true), 4 (mostly true) and 5 (completely true). The response scale numbers for negative items have all been reversed on the score sheet in order to permit a simple, unified scoring system. By this system a person who says completely false to a negative item obtains a high score just as he does when he says completely true to a positive item. Thus high scores uniformly mean positive self-description.

\subsection{Procedure}

The study involved a 2 (academically competent adolescents versus academically less-competent adolescents) $\times 2$ (boys versus girls) factorial design. The self-concepts of participants of all the four groups were compared which included their physical self, moral self, personal self, family self, social self and overall self.

\section{Results}

The present investigation has employed multi-criteria measures of self- concept. As shown in Table 1, it has been found that almost all the dimensions are positively related to each other in case of boys. Moreover the relationship between overall self-concept and each of the dimensions of self-concept reveals significant correlations. But it has been found that the association between personal self and overall self is very high $\mathrm{r}(118)=0.84, p<.01$ in case of boys. It has been also found that although there is positive association among different dimensions of self-concept as well as overall self-concept in case of girls, but association between physical self- concept and overall self-concept and again between social self-concept and overall self-concept is very high $\mathrm{r}(118)=0.84, p<.01$ and $\mathrm{r}(118)=0.82, p<.01$ respectively.

\section{Table 1}

Inter-correlations among different dimensions of Self-concept obtained from adolescent boys $(n=120)$ and girls $(n=120)$

\begin{tabular}{|c|c|c|c|c|c|c|}
\hline Dimensions of Self-concept & $\begin{array}{c}\text { Physical } \\
\text { Self }\end{array}$ & $\begin{array}{c}\text { Moral } \\
\text { Self }\end{array}$ & $\begin{array}{l}\text { Personal } \\
\text { Self }\end{array}$ & $\begin{array}{c}\text { Family } \\
\text { Self }\end{array}$ & $\begin{array}{c}\text { Social } \\
\text { Self }\end{array}$ & $\begin{array}{c}\text { Overall } \\
\text { Self }\end{array}$ \\
\hline Physical Self & & $.44 *$ & $.60 *$ & $.54 *$ & $.48 *$ & $.84 *$ \\
\hline Moral Self & $.31 *$ & & $.55^{*}$ & $.49 *$ & -.02 & $.67 *$ \\
\hline Personal Self & $.25^{*}$ & $.41 *$ & & $.60 *$ & .16 & $.32 *$ \\
\hline Family Self & .13 & $.51 *$ & $.30 *$ & & $.24 *$ & $.65^{*}$ \\
\hline Social Self & .05 & $.28 *$ & -.04 & $.26^{*}$ & & $.82 *$ \\
\hline Overall Self & $.41 *$ & $.67 *$ & $.84^{*}$ & $.51 *$ & $.47 *$ & \\
\hline
\end{tabular}

Note. ${ }^{*} p<.01$ Correlations above the diagonal are for the girls and below the diagonal are for the boys.

The summary of the analysis of variances of academically competent adolescent students versus less-competent ones and boys versus girls on different dimensions of self-concept are presented in Table 2. While, the summary of the mean ratings of the participants on different dimensions self-concept is presented in Table 3.

The Analysis of Variances (ANOVA) performed on different dimensions of self-concept indicate significant main effect for academic achievement in case of physical self, moral self, personal self, family self, social self and overall self, $\mathrm{F}(1,236)=152.73, p<.01, \mathrm{~F}(1,236 \quad 95.23, p<.01, \mathrm{~F}(1,236)=55.14, p<.01, \mathrm{~F}(1,236)=50.32, p<.01$, $\mathrm{F}(1,236)=15.40, p<.01$, and $\mathrm{F}(1,236)=205.77, p<.01$, respectively (See Table 2). As shown by Table 3, academically competent adolescents have better physical, moral, personal, family, social and overall self-concept than academically less-competent adolescents $(\mathrm{M}=63.30 \& 54.84, \mathrm{M}=67.20 \&$ \& 60.32, $\mathrm{M}=68.96$ \& 62.52 , $\mathrm{M}=66.67 \& 60.82, \mathrm{M}=60.97 \& 58.05, \mathrm{M}=327.09 \& 296.55$, respectively).

The analysis of variances (ANOVA) performed on different dimensions of self-concept indicate significant main effect for sex in case of physical self, personal self, family self and social self, $\mathrm{F}(1,236)=109.39, p<.01$, 
Adolescent's self-concept: Understanding the role of gender and academic competence

$\mathrm{F}(1,236)=130.02, p<.01, \mathrm{~F}(1,236)=103.84, p<.01, \mathrm{~F}(1,236)=112.05, p<.01$ respectively (see Table 2). As shown by Table 3, males have better physical self and personal self-concept than females $(M=62.65 \& 55.49), M=70.68$ \& 60.79, respectively). Again, females have higher family self and social self-concept than males $(\mathrm{M}=67.94 \&$ $59.55, \mathrm{M}=63.44 \& 55.57$, respectively). The analysis of variances performed on moral self- concept and overall self-concept show non-significant effect for sex, $\mathrm{F}(1,236)=2.89, \mathrm{~F}(1,236)=.87$, not significant respectively (see Table 2) As shown by Table-3 males and females do not differ in case of moral self-concept and overall self-concept (M=64.36 \& 63.16, M=312.82 \& 310.83, respectively).

Table 2

Summary of the analysis of variances performed on different dimensions of self-concept of participants

\begin{tabular}{|c|c|c|c|c|}
\hline Self-concept Dimensions & Sources & $\underline{\mathrm{df}}$ & $\underline{\mathrm{MS}}$ & $\underline{F}$ \\
\hline \multirow{4}{*}{ Physical Self } & Status & 1 & 4292.60 & $152.73 *$ \\
\hline & Sex & 1 & 3074.50 & $109.39 *$ \\
\hline & Status X Sex & 1 & 75.93 & 2.70 \\
\hline & Error & 236 & 28.10 & \\
\hline \multirow{4}{*}{ Moral Self } & Status & 1 & 2842.81 & $95.23 *$ \\
\hline & Sex & 1 & 86.40 & 2.89 \\
\hline & Status X Sex & 1 & 336.06 & 11.25 \\
\hline & Error & 236 & 29.85 & \\
\hline \multirow{4}{*}{ Personal Self } & Status & 1 & 2489.70 & $55.14 *$ \\
\hline & Sex & 1 & 5870.70 & $130.02 *$ \\
\hline & Status X Sex & 1 & 148.83 & 3.29 \\
\hline & Error & 236 & 45.14 & \\
\hline \multirow{4}{*}{ Family Self } & Status & 1 & 2047.50 & $50.32 *$ \\
\hline & Sex & 1 & 4425.20 & $103.84 *$ \\
\hline & Status X Sex & 1 & .03 & .001 \\
\hline & Error & 236 & 40.69 & \\
\hline \multirow{4}{*}{ Social Self } & Status & 1 & 510.41 & $15.40 *$ \\
\hline & Sex & 1 & 3713.06 & $112.05^{*}$ \\
\hline & Status X Sex & 1 & 32.26 & .97 \\
\hline & Error & 236 & 33.13 & \\
\hline \multirow{4}{*}{ Overall Self } & Status & 1 & 55967.60 & $205.77 *$ \\
\hline & Sex & 1 & 238.01 & .87 \\
\hline & Status X Sex & 1 & 2001.03 & 7.35 \\
\hline & Error & 236 & 271.98 & \\
\hline
\end{tabular}

Note. ${ }^{*} p<.05$

\section{Discussions}

The present study provides empirical evidence supporting the role of academic competence (high and low) and gender on different dimensions of self- concept of adolescents. The findings clearly showed that academically competent adolescent students have higher self-concept (physical, moral, personal, family and social self) than less-competent ones. Nowadays, academic achievement is considered a key criterion to judge one's total potentialities and capabilities. Academically competent adolescents feel higher sense of personal worth and somewhat better about themselves. Those who have higher academic competence tend to feel more active, capable and confident than those who have less competence. Performance in academic task enhances sense of self-esteem and personal control because academically competent persons are always praised and appreciated and they have more importance in the society. In family, also academically competent children are more accepted and responded positively.

High level of competence promotes better mental health of a person across a wide range of social skills. The result is consistent with the results of the previous researches conducted in India and abroad. Krishnan (1993) 
Rath, S. \& Nanda, S.

found a significant relationship between self-concept and academic achievement in case of college students. Malbi and Reasoner (2000) found from their investigations that good academic grades could enhance one's sense of worthiness and competence.

Table 3

Summary of the mean ratings on different dimensions of self-concept of participants

\begin{tabular}{|c|c|c|c|c|c|c|}
\hline \multirow{2}{*}{$\begin{array}{l}\text { Self-concept } \\
\text { Dimensions }\end{array}$} & \multirow{2}{*}{ Groups } & \multicolumn{2}{|c|}{ Boys } & \multicolumn{2}{|c|}{ Girls } & \multirow{2}{*}{ Combined $\mathrm{M}$} \\
\hline & & M & $S D$ & M & $S D$ & \\
\hline \multirow[t]{3}{*}{ Physical Self } & $\begin{array}{l}\text { Academically } \\
\text { competent }\end{array}$ & 66.32 & 7.08 & 60.28 & 3.80 & 63.30 \\
\hline & Less-competent & 58.98 & 6.72 & 50.70 & 1.55 & 54.84 \\
\hline & Combined & 62.65 & - & 55.49 & - & - \\
\hline \multirow[t]{3}{*}{ Moral Self } & $\begin{array}{l}\text { Academically } \\
\text { competent }\end{array}$ & 66.62 & 6.07 & 67.78 & 5.19 & 67.20 \\
\hline & Less-competent & 62.10 & 4.24 & 58.53 & 6.12 & 60.32 \\
\hline & Combined & 64.36 & - & 63.16 & - & - \\
\hline \multirow[t]{3}{*}{ Personal Self } & $\begin{array}{l}\text { Academically } \\
\text { competent }\end{array}$ & 73.12 & 8.86 & 64.80 & 7.12 & 68.96 \\
\hline & Less-competent & 68.25 & 6.45 & 56.78 & 3.08 & 62.52 \\
\hline & Combined & 70.68 & - & 60.79 & - & - \\
\hline \multirow[t]{3}{*}{ Family Self } & $\begin{array}{l}\text { Academically } \\
\text { competent }\end{array}$ & 62.48 & 7.44 & 70.85 & 7.30 & 66.67 \\
\hline & Less-competent & 56.62 & 6.21 & 65.03 & 3.93 & 60.82 \\
\hline & Combined & 59.55 & - & 67.94 & - & - \\
\hline \multirow[t]{3}{*}{ Social Self } & $\begin{array}{l}\text { Academically } \\
\text { competent }\end{array}$ & 56.67 & 5.44 & 65.27 & 7.30 & 60.97 \\
\hline & Less-competent & 54.48 & 3.77 & 61.62 & 5.94 & 58.05 \\
\hline & Combined & 55.57 & - & 63.44 & - & - \\
\hline \multirow[t]{3}{*}{ Overall Self } & $\begin{array}{l}\text { Academically } \\
\text { competent }\end{array}$ & 325.20 & 20.39 & 328.98 & 19.31 & 327.09 \\
\hline & Less-competent & 300.43 & 12.01 & 292.67 & 12.43 & 296.55 \\
\hline & Combined & 312.82 & - & 310.83 & - & - \\
\hline
\end{tabular}

A study by Hollingsworth (2009) showed that the distribution of high academic scores in reading, language and mathematics was with the students who had high scores in their social and physical self-pattern and the distribution of low academic scores in reading, language and mathematics was with the students who had low scores in their social and physical self-pattern. Less-competent adolescents having low self-concept may be given intensive remedial training. They may be provided academic assistance comprised with social support and special counseling.

The findings reveal that adolescent boys outperform girls in personal and physical self but adolescent girls outperform boys in family and social self. But there is no gender difference in overall self-concept. This finding indicates that there are certain traits that are differently ascribed for boys and girls. Gender differences exist in some important domains of life. The finding also reveals that there is no gender difference with respect to moral self-concept. Meta-analytic reviews of gender difference on traditional moral reasoning tasks do not reveal a clear-cut picture (Thoma, 1986). 
It has been found that although boys have more physical self-concept than girls, but the strength of association between physical self-concept and overall self-concept in girls is higher than that of boys. Physical appearance is a powerful contributor to self-esteem in adolescent girls (Harter, 2006). In Harter's research, physical appearance consistently correlated with global self-esteem. In our society, physical attractiveness is considered a more appropriate criterion for assessing girls than boys. In case of girls, looking attractive is considered more feminine than doing well in academic field.

Physically attractive girls receive more favorable treatment and help from others and they are more positively evaluated at work. Presumably, less attractive girls are more likely to be lonely, which means they are more likely to be stigmatized. This means that self-esteem is closely related to acceptance and satisfaction with a physical self (Padin, Lerner, \& Spiro, 1981; Pomerantz, 1979).

This societal emphasis on attractiveness has an unfortunate impact on the self-esteem of girls, because many of them consider themselves to be unattractive. At least in part, this negative self-perception explains why studies in a wide range of countries have found that, on average, girls have a lower sense of physical self-esteem than boys do (Harter, 1999; Wichstrom, 1998). Probably because physically attractive girls are treated more favorably, they tend to become more confident and do have better social skills (Goldman \& Lewis, 1977; Hatfield \& Sprecher, 1986). Presumably, the popularity, social skills, high self-esteem, and tendency to self-disclose among those who are attractive occur primarily because such individuals have spent their lives being liked and treated nicely by others who respond positively to their good looks (Zebrowitz, Collins, \& Dutta, 1998). This positive evaluation increases the self-esteem of physically attractive girls.

The present study also reveals that girls have higher social self-concept compared to boys. The strength of association between social self-concept and overall self-concept in girls is much higher than the association found in boys. Interestingly, the strength of association between personal self-concept and overall self-concept in boys is much higher than the association found in girls. In our society, girls appear to be more self-conscious, more concerned with others' opinions about them, more eager to avoid behavior eliciting negative reactions than boys. They are more eager to be liked, more desirous of making a favorable impression on others. Girls' concerns with relationships may lead them to express emotions that strengthen relationships and inhibit emotions that could harm relationships (Timmers et al 1998). This suggests that girls become much more "other-directed" or "people-oriented" than boys. Their self-consciousness may derive from the fact that they are much more concerned with other's attitudes towards them and thus tend to see themselves through the eyes of others.

To adolescent girls, interpersonal success acquires prime importance. Women prefer collaboration, consultation and negotiation rather than the more masculine tradition of competition, individual achievement and demands (Rosener, 1990). Women may have better social skills than men because they have to (Margalit \& Eysenck, 1990). Women get pleasure and self-satisfaction by contributing to others' well-being which increases their social self-concept. This finding is consistent with research conducted by Andrew (2002) that males scored significantly lower on social self-concept than females.

Boys are expected to become independent, ambitious, competitive, self-reliant, and achievement oriented. Boys are taught to be assertive, whereas girls are taught to express concern for others and to control their assertion. Boys are basically independent and they have the motive to express power and control over others. They are less vulnerable to criticism or disapproval of others than girls. This sense of adequacy increases the personal self-concept in case of boys. Research indicates that these gender differences are related to person's self-esteem (Markus, 1992). For men, self-esteem is linked to individual personal achievement while for women self-esteem is a function of interpersonal attachment to specific others.

Sex differences exist in self-perception. Women are more likely than men to attach great importance to their overall body image (Pliner, Chaiken, \& Flett, 1990). This difference appears to be pan-cultural. In defining one's sense of self women are more concerned with relationship and connection whereas men are oriented towards separation and individuation. Men and women constructing this sense of self largely in terms of personal or 
relational paradigm are not specific to Indian culture. This trend holds true across a number of different cultures. The sources of these differences are debatable. The biological model assumes that gender differences are rooted in evolutionary processes and there is a stable genetic and hormonal difference. This view point is challenged by socio-cultural model which holds that gender roles are socially constructed and traditional gender roles reflect subordinate status of females. Women give more importance to physical attractiveness than men arises from the power relations rather than stable genetic differences. A history of social pressure to accept second place in assertive and aggressive situation may be the reason that women are less likely to emphasize masculine behavioral style. Women tend to outperform in social skills (Margalit \& Eysenck, 1990) makes sense that the ability to avoid angry interactions and to compromise are of special value to those who have denied access to power.

\section{Conclusion}

These findings emphasize new approaches to the development of self, emphasizing the active role of individuals to make better sense of the world, and the powerful influence of cultural surroundings on individual thinking and behavior (Meltzoff \& Gopnik, 1997). People are not born with characteristics of men and women, individualistic or collectivistic orientation, high or low self-esteem, and so on. Rather they become adults with certain characteristics through being taught and trained in particular culture.

\section{References:}

Andrew, C. B., (2002). Job satisfaction among women in relation to their family environment. Journal of Community Guidance and Research, 11, 49-50.

Bell, C., \& Ward, G. R. (1980). An investigation of the relationship between dimensions of self-concept (DOSC) and achievement in mathematics. Adolescence, 15, 895-901.

Cross, S. E., \& Madson, L. (1997). Models of the self: Self-construals and gender. Psychological Bulletin, 122, 5-37. <http://dx.doi.org/10.1037/0033-2909.122.1.5>

Cwiok, E., (1996). The self-concept of intellectually gifted and average students of secondary school [In Polish]. Psychologia Wychowawcza, 2, 140-147.

Feingold, A. (1990). Gender differences in physical attractiveness on romantic attraction: A comparison across five research domains. Journal of Personality and Social Psychology, 59, 981-993. $<$ http://dx.doi.org/10.1037/0022-3514.59.5.981>

Goldman, W., \& Lewis, P. (1977). Beautiful is good: Evidence that the physically attractive are more socially skillful. Journal of Experimental Social Psychology, 13, 125-130. $<$ http://dx.doi.org/10.1016/S0022-1031(77)80005-X>

Hamachek, D. E. (1981). Encounters with the ego [In Mexican]. Mexico: Interamericana.

Harter, S. (1986). Processes underlying children's' self-concept. In J. Sule (Ed.), Psychological perspectives in the self (vol. 3). Hillsdale, New Jersey: Lawrence Erlbaum Associates.

Harter, S. (1999). The Construction of the self: A developmental perspective. New York: Guilford Press.

Harter, S. (2006). The development of self-representations in childhood and adolescence. In W. Damon \& R. Lerner (Eds.), Handbook of child psychology (6th ed.). New York: Wiley.

Hatfield, E., \& Sprecher, S. (1986). Mirror, mirror .... The importance of looks in everyday life. Albany: SUNY Press.

Hollingsworth, M. A. (2009, March). Wellness and academic performance of elementary students. Paper based on a program presented at the American Counseling Association Annual Conference and Exposition, Charlotte, NC.

Josephs, R. A., \& Markus, H. R. (1992). Gender and self-esteem. Journal of Personality and Social Psychology, 63, 391-402. <http://dx.doi.org/10.1037/0022-3514.63.3.391>

Krishnan, S. (1993). Relationship between self-concept and academic achievement of college students. The 
Progress of Education, 67(10/11), 235-238.

Machargo, J. (1991). The teacher and self-concept in his or her students. Theory and practice [In Spanish].

Madrid: Escuela. Espanola.

Malbi, R. S., \& Reasoner, R. W. (2000). Self-esteem, enhancing. Kuala Lumpur: Self-esteem Seminars Sdn. Bhd.

Margalit, M., \& Eysenck, S. (1990). Prediction of coherence in adolescence: Gender differences in social skills, personality, and family climate. Journal of Research in Personality, 24, 510-521.

$<$ http://dx.doi.org/10.1016/0092-6566(90)90036-6>

Marsh, H. W., \& Yeung, A. S. (1997). Casual effects of academic self-concept on academic achievement: Structural equation models of longitudinal data. Journal of Educational Psychology, 89, 41-54. $<$ http://dx.doi.org/10.1037/0022-0663.89.1.41>

Marsh, H., \& Hattie, S. (1996). Theoretical perspectives on the structure of self-concept. In B. A. Barcken (Ed.), Handbook of self-concept (pp. 38-90). New York: Wiley.

Meltzoff, A. N, \& Gopnik, A. (1997). Words, thoughts, and theories. Cambridge, MA: MIT Press.

Oliva, P. (1999). School years: Young women, self-esteem and the confidence gap. New York: Doubleday.

Orenstein, P. (1994). School years: Young women, self-esteem and the confidence gap. New York: Doubleday.

Padin, M. A., Lerner, R. M., \& Spiro, A., III. (1981). Stability of body attitudes and self-esteem in late adolescents. Adolescence, 16, 271-384.

Pliner, P., Chaiken, S., \& Flett, G. L. (1990). Gender differences in concern with body weight and physical appearance over the lifespan. Personality and Social Psychology Bulletin, 16, 263-273. $<$ http://dx.doi.org/10.1177/0146167290162007>

Pomerantz, S. C. (1979). Sex differences in the relative importance of self-esteem. Physical self-satisfaction and identity in predicting adolescent satisfaction. Journal of Youth and Adolescence, 8, 51-61. <http://dx.doi.org/10.1007/BF02139139>

Rosener, J. B. (1990). Ways women lead. Harvard Business Review, 68(6), 202.

Shavelson, R. J., Hubner, J. J., \& Stanton, J. C. (1976). Self-concept: Validation of construct interpretations. Review of Educational Research, 46, 407-441.

Strathe, M., \& Hash, V. (1979). The effect of an alternative school in adolescent self-esteem. Adolescence, 14, 185-189.

Thoma, S. J. (1986). Estimating gender differences in the comprehension and preference of moral issues. Developmental Review, 6, 165-180. <http://dx.doi.org/10.1016/0273-2297(86)90010-9>>

Timmers, M., Fischer, A. H., \& Manstead, A. S. R. (1998). Gender differences in motives for regulating emotions. Personality and Social Psychology Bulletin, 24, 974-985. <http://dx.doi.org/10.1177/0146167298249005>

Wichstrom, L. (1998). Self-concept development during adolescence: Do American truths hold for Norwegians? In E. E. A. Skoe \& A. L. Von der Lippe (Eds.), Personality development in adolescence: Across national and life span perspective (pp. 98-122). New York: Routledge.

Zebrowitz, L. A., Collins, M. A., \& Dutta, R. (1999). The relationship between appearance and personality across the life span. Personality and Social Psychology Bulletin, 24, 736-749. <http://dx.doi.org/10.1177/0146167298247006> 
Rath, S. \& Nanda, S. 